\title{
Power to the people: a wiki-governance model for biobanks
}

\author{
Edward S Dove*, Yann Joly and Bartha M Knoppers
}

\begin{abstract}
Biobanks are adopting various modes of public engagement to close the agency gap between participants and biobank builders. We propose a wiki-governance model for biobanks that harnesses Web 2.0, and which gives citizens the ability to collaborate in biobank governance and policymaking.

Keywords Biobank, collaboration, genomics, governance, networks, public participation, social media, Web 2.0.
\end{abstract}

Participatory democracy, deliberative democracy and related models of inclusive, public engagement have recently gained a formidable foothold in biobank, genomics and science-and-society literature [1-9]. Despite its relative nascency, public engagement is already eradicating once-enshrined technocrat beliefs of expertdriven, top-down governance [10]. Indeed, public engagement is increasingly being implemented by biobanks around the world to close a perceived agency gap; witness the (Canadian) BC Generations Project's adaptive governance structure that includes the structural incorporation of participant interests into governance via participant bodies [8] and the UK Biobank's reflexive governance model that pushes for wide-ranging and ongoing commitment to stakeholder engagement [11]. Although there are many types of biobanks (Table 1), one may arguably postulate that a consensus is emerging in largescale, public, population-based biobank governance: the collective, public nature of a biobank's constitution and stored material in the form of data and samples militates strongly in favor of the active involvement of contributors in decisions regarding the allocation and stewardship of biobank resources.

*Corresponding author: Edward S Dove: Edward.dove@mail.mcgill.ca Centre of Genomics and Policy, Department of Human Genetics, Faculty of Medicine, McGill University, 740 Dr Penfield Avenue, Suite 5200, Montreal, Quebec, H3A OG1, Canada
Given that many large-scale, population-based biobank projects are funded, regulated and sometimes managed by the state, meaningful engagement with tax-paying citizens is critical to build and sustain public trust and involvement. Public engagement in biobanks is manifold, ranging from information dissemination on biobank websites and town-hall-style panels and workshops, to community representatives serving on biobank boards and, in some cases, full power sharing. While these engagement modalities are an improvement from the relic models of top-down, expert-driven discretionary governance [12] that led to democratic deficits, sustained public criticism (for example, the Human Genome Diversity Project [13], UmanGenomics in Sweden [14], and the proposed biobank project in the Kingdom of Tonga [15]), or legislative failures (for example, the Health Sector Database Act in Iceland [16]), they too suffer several shortcomings.

These models may not: sufficiently reflect the values and interests of all stakeholders; be solution-driven; be fully transparent, accountable or non-arbitrary; or be fully independent from biobank management. Mere publication of policies for passive consumption is unidirectional transparency that forecloses any ability to engender openness and participation. Ethics and governance committees, even if composed of contributors or other stakeholder representatives to police decisionmaking, might be regarded as merely legitimating the decision-making and actions by the biobank itself and might not have real independence and access to effective enforceability mechanisms (for example, binding power to levy a fine or withdraw access privileges upon a material violation of a data or sample usage agreement) to act as a watchdog with teeth [17]. Some commentators have proposed innovative ideas. David Winickoff, for example, has proposed a shareholder model $[18,19]$ that adopts a cooperative, charitable trust and corporate law outlook that allows participants to exert a share of control in distributive decision-making via representation by an elected donor association. Potentially beneficial for disease-based biobanks, it would be likely to encounter logistical and policy-oriented problems in large-scale, population-based projects, and engage only biobank 
Table 1. General typology of biobanks

\begin{tabular}{|c|c|}
\hline Classification & Characteristics (non-exhaustive) \\
\hline Nature & $\begin{array}{l}\text { De novo (prospective) } \\
\text { Retrospective collection of biological } \\
\text { samples and associated data }\end{array}$ \\
\hline Type & $\begin{array}{l}\text { Population-based } \\
\text { Disease-based }\end{array}$ \\
\hline Age cohort & $\begin{array}{l}\text { Adult } \\
\text { Pediatric }\end{array}$ \\
\hline Purpose of collection & $\begin{array}{l}\text { Clinical trial } \\
\text { Pathological archive } \\
\text { Basic research } \\
\text { Translational study } \\
\text { Public health } \\
\text { Forensic }\end{array}$ \\
\hline Size and scope & $\begin{array}{l}\text { Specific community/communities } \\
\text { Regional } \\
\text { National } \\
\text { International }\end{array}$ \\
\hline Nature of biological samples & $\begin{array}{l}\text { DNA/RNA } \\
\text { Blood } \\
\text { Serum } \\
\text { Tissues } \\
\text { Urine } \\
\text { Saliva }\end{array}$ \\
\hline Type of data & $\begin{array}{l}\text { Genetic } \\
\text { Phenotypic } \\
\text { Health related } \\
\text { Genealogical } \\
\text { Lifestyle }\end{array}$ \\
\hline Period of storage & $\begin{array}{l}\text { Fixed } \\
\text { Indefinite }\end{array}$ \\
\hline Level of security & $\begin{array}{l}\text { Coded } \\
\text { Anonymized } \\
\text { Anonymous }\end{array}$ \\
\hline Funding & $\begin{array}{l}\text { Public } \\
\text { Private } \\
\text { Public-private }\end{array}$ \\
\hline Venue & $\begin{array}{l}\text { Hospital } \\
\text { Academic or research institution } \\
\text { Governmental institution } \\
\text { Industry } \\
\text { Foundation or disease-advocacy } \\
\text { organization }\end{array}$ \\
\hline
\end{tabular}

Biobanks may be generally defined as an organized collection of human biological material and associated information stored for one or more research purposes. As this table illustrates, there is an open-ended and potentially nonexclusive typology in the rich tapestry of biobanks $[25,68]$, but many stand at the intersection of multiple issues such as medicine, science, markets and public health [56]. This article focuses on large-scale, longitudinal, publicly funded, population-based biobanks. A population-based biobank has the following characteristics, based on the Council of Europe criteria [69]: (i) the collection has a population basis; (ii) it is established, or has been converted, to supply biological materials or data derived therefrom for multiple future research projects; (iii) it contains biological materials and associated personal data, which may include or be linked to genealogical, medical and lifestyle data, and which may be regularly updated; and (iv) it receives and supplies materials in an organized manner. Table adapted from [70].

participants - not all stakeholders in the biobank ecosystem $[1,11]$.

Thus, there is a real potential for citizens to be lulled into a false reassurance of sound, representative ethical and governance approbation. This gives cause for concern and thought for better avenues of non-hierarchical engagement and oversight for large-scale, populationbased biobanks. We therefore propose an alternative networked, reciprocity and mutuality-driven model $[20,21]$ that engages all citizens actively [22] and that is not co-constructed or shaped top-down by state or other political authorities [23].

\section{How wiki-governance would work: open but structured}

In this wiki-governance model (Figure 1), taxpayer-funded, large-scale, population-based biobanks would harness Web 2.0 and the age of networks. Working in conjunction with funders and regulators, biobank builders would create and steward a social-media driven HTTP Secure online forum where publics (conceivably but not necessarily state citizens if the biobank is national, and global citizens if the biobank is international) would register (via username, password and email address) and collaborate in proposing, drafting and amending biobank digital governance structures, protocols, strategies and policies. Citizens would have the option of using either their username or their real name as a publicly visible author's name for content they submit. Unlike a crowdsourcing model that entails herds rushing to a problem, wiki-governance entails structured coordination of issue framing and role differentiation where individuals can choose the opportunities that best exploit their intelligence and represent their interests [24]. Forums, polls, digital libraries of past and comparative policies and documents, and chat interfaces would enable interested individuals to educate themselves about the biobank and the general scientific, ethical, legal and regulatory framework that girds it, such as laws concerning human material or data protection and regulatory bodies.

Though each biobank would contain individually tailored key policies, within the genus of populationbased biobanks, there would be a structured set of minimum standards or permissible policies or practices, guided by legal and ethical doctrines [25] or generally accepted governance desiderata such as adaptability, coherence and internal consistency $[11,26]$. Individuals and interest groups would be empowered to winnow out, vote and comment on draft provisions or policies, such as a broad consent form, an access policy for samples and data, a return of results policy, or a model benefit-sharing agreement, as well as respond to comments posted by others. After engaging in such open and visual deliberation, the biobank's management (or similar) committee would then act as final arbiters in determining if and when a given policy should be adopted as final, and whether its contents are scientifically, ethically and legally valid (Box 1). This collaborative knowledge ecosystem 


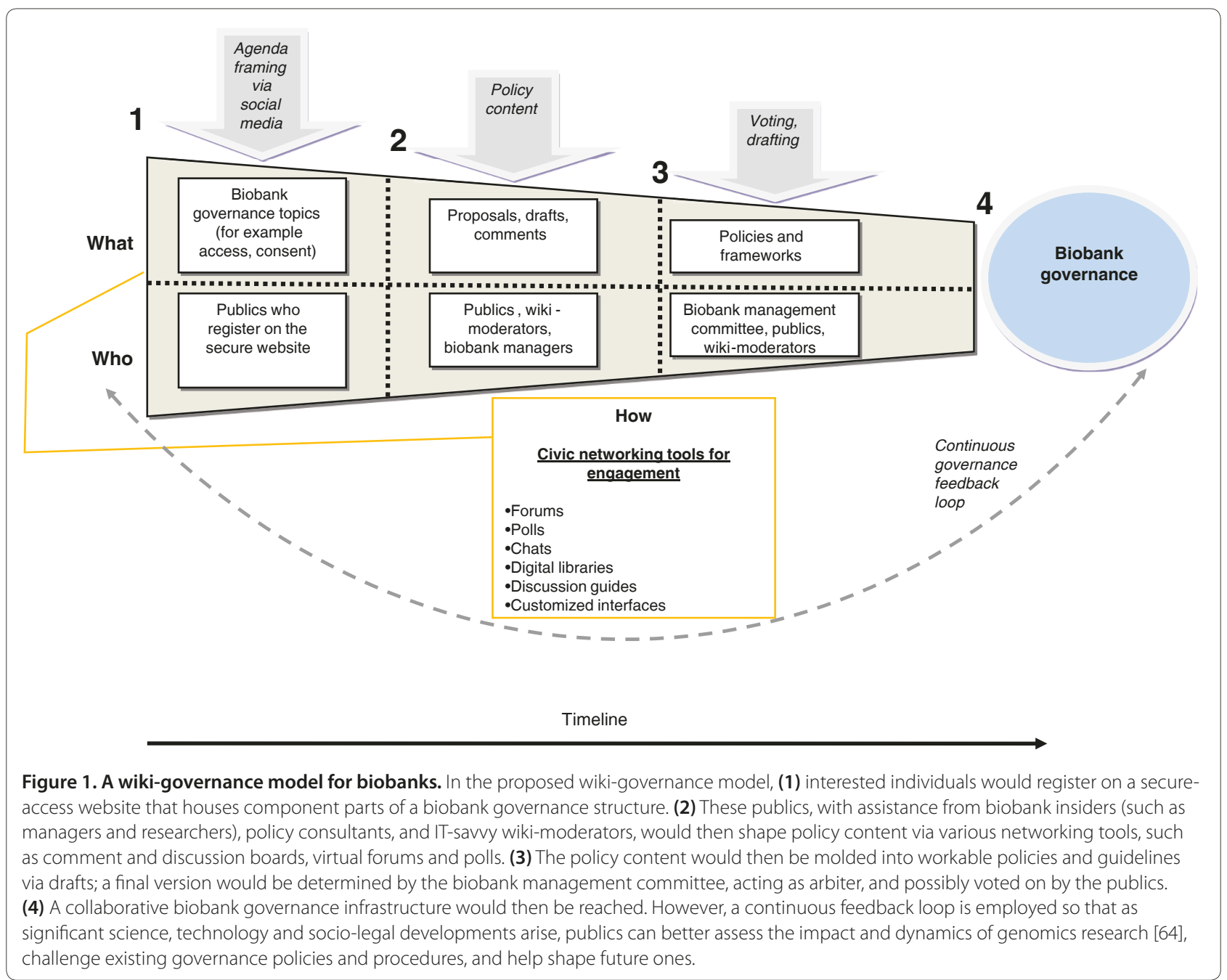

and subsidiarity structure is similar to how Wikipedia works successfully, where registered users may edit the contents of entries, which are then subject to peer approval and reviewed and validated by a group of core editors [27].

While wiki-governance may be viewed as a cousin of collectively engaged projects that allow scientists to annotate gene functions, protein structures and other information relevant to genome biology [28-33], as well as the growing citizen scientist movement [34-37], it is readily distinguishable from both. Wiki-governance is open to all citizens, not just traditional, expert-led communities of scientists; as a governance system, it avoids the potential pitfall of data inconsistency that could plague wiki biological databases [38]. Unlike projects that consist of individuals posting their DNA sequences in the public domain for various experiments (for example, Personal Genome Project, OpenSNP, Genomera), wiki-governance does not involve citizens collecting and analyzing raw data and directly engaging in studies and trials (or proposing new ones), which carry unique scientific, legal and ethical issues.

Envisioned instead as a collaborative enterprise for governance (as opposed to research) purposes, wikigovernance would, in our view, greatly advance participation among biobank managers (and other insiders) and publics, be they contributors and their families or the greater citizenry. Rather than targeting a selected group of individuals as representatives of the public (as is often the current governance model), wikigovernance would, like current examples of citizen lawmaking (Box 2), attempt to reach across all segments of society for inclusive engagement and partnership [39] and allow citizens to work alone or in self-identified groups. It would pool diverse knowledge and skills [40] and make public engagement 'an integral part of the overall governance structure of the biobank' [41]. It would satisfy demands by the public for 'clear preferences for the design of biobanks' [42]. Most importantly, wiki-governance would produce a higher 


\section{Box 1. A hypothetical biobank wiki-governance scenario}

The following is a very brief sketch of a hypothetical scenario for wiki-governance in a biobank. We wish to emphasize that each situation will call for creative and customized strategies, methodology, and tools that are carefully and transparently planned with multidisciplinary involvement.

Nulleterre Biobank, a prospective, national, population-based biobank, wants to formulate a policy on consent, as well as a consent form, for participation in the biobank. Its management/scientific committee, in consultation with the advisory board, decides to use social media to encourage publics to visit and register on its secure website to partake in the task'to develop a consent form and policy for Nullepart Biobank'. Part of the agenda framing exercise is to invite individuals to work on specific tasks or address targeted questions. The general issue is framed as: 'Nullepart Biobank wants to create a pool of openly available samples and data that realistically maintain and respect privacy. Our goal is to create a policy that allows people to donate their samples and data to our biobank and have them coded so that they can be securely delivered to all researchers around the world. The researchers must agree to strict conditions that prevent harm to the contributors and to share their research results freely. Contributors would have to go through a detailed informed consent process that includes online tutorials and information sessions and culminates in signing a comprehensive consent form'. Further background information is available on the website, as are clear instructions on the wiki-governance process.

Topics are parsed into component parts, including: general comments or voting on the proposal; responding to targeted questions; posting relevant background literature, laws or policies; drafting specific parts of the consent form; comments on and edits of particular consent form provisions already drafted; and producing the online tutorial. Individuals then self-select into groups and digitally and visually collaborate on responding to the specific parts depending on their interests, expertise and time availability. Wiki-moderators are available online to oversee the forum and help those who have technical questions, and policy consultants are available to address policy-oriented questions. The endeavor has an open period of 1 year, at which point the website is closed to further collaboration.

After the 1-year period expires, the scientific committee of Nulleterre Biobank, in consultation with the advisory board, reviews the various submissions and validates them. It decides to adopt the consent policy and accept most of the draft consent form. It rejects part of the drafted 'risks' section for ethical reasons, explaining them in detail, and states that it will need to add two short, currently absent sections on sources of funding and use after death (these in turn will be open for public comment and drafting for a further period of 1 month). The biobank also states that before implementing the policy and the consent form, it will vet them with its legal counsel, and that the policy and consent form will be continuously updated and revised through the wiki-governance system on an ongoing basis as new scientific, technical, ethical and legal issues arise.

quality biobank governance infrastructure for the following reasons.

First, biobanks would truly engage and appeal to their publics, welcoming contributions from all, yet without compelling any given individual or group to participate at a de minimus level. Each person would be entitled to contribute as much or as little perspective and skills as desired, and this could potentially deflect future criticisms of a biobank's operations [43]. At the same time, by engaging publics via virtual networks and a dynamic digital commons for outputs and action (that is, collaboratively evaluating and shaping information in order to create implementable solutions), wiki-governance would be likely to abate the pitfalls of consensus-driven, deliberative governance models involving both traditional, confined face-to-face and online encounters that fixate on inputs. Inputs focus on gathering diverse viewpoints and balanced representation for opinion formation and adherence to procedural rules for interaction that may produce endless talk and groupthink [44-46]. Second, the infrastructure would be the product of assorted, unbiased, non-insider opinions and skills untethered to the scientific imperative fuelling biobankers, researchers and the funding agencies. Third, wiki-governance would facilitate a continuous feedback loop. As underlying science (for example, next-generation DNA sequencing) and technology (for example, cloud computing) advances and new ethical and legal issues arise (for example, return of research results and incidental findings), perpetual public dialogue would provide desired flexibility, adaptability and reflexivity, thereby consistently challenging existing governance policies and procedures and anticipating which challenges might arise $[11,47]$.

Finally, though the governance structure may exhibit a form of non-legally binding self-regulation, its communitycollaborative construction would be likely to impose a stronger level of control and influence on the behavior of the biobank: failure to uphold the policies formulated by citizens would be likely to cause a loss of public support and trust, and jeopardize the viability of both the biobank in question and future biobanks. Put another way, publicly crafted and citizen watch governance policies that are self-regarding can better convince outsiders that there are robust checks on insider conduct in place, as opposed to many hard law sanctions [27]. Moreover, as Graeme Laurie aptly remarks, 'the irony is that if recourse to law is needed even within traditional regulatory systems then the systems have already failed' [11]. 


\section{Box 2. Wiki-governance in action: citizen lawmaking}

While of novel terrain in the field of genomics and biobank governance, wiki-governance examples are thriving in state and citizen-led efforts to increase public engagement in lawmaking [24]:

New York Law School's Democracy Design Workshop and Do Tank is a laboratory of governance innovation ideas [71].

Russia recently participated in WikiVote [72] by posting a draft bill on fishing in public waterways [73]. The draft bill went through two redrafts and received over 1,000 proposed modifications [73]. Russia has also since posted a draft education bill on WikiVote [74].

In July 2007, Estonia launched its Osalusveeb portal [75] (osale means participate in Estonian) whereby Estonians can initiate legislative proposals, submit petitions to the government, participate in public hearings and comment on draft legislation proposed by the government.

In 2007, citizens and non-citizens (for example, international constitutional commentators, policing experts and criminologists) alike helped revise the Police Act 1958 in New Zealand via a wiki, which received more than 25,000 visits during the year [24,76]. While certain ideas, such as renaming the force 'The New Zealand Yum-Yum Teddy Bear Strike Force Z', were edited out, others were put into the new Policing Act 2008, including a suggestion to increase the minimum police recruitment age to 25 , since research indicates that the human brain is not fully developed until then [76].

In June 2009, Brazil launched the e-Democracia Project [77]. It allows Brazilians to share information about a problem that a law may address, identify and discuss potential solutions to the problem, and draft a bill. Further, it transports citizen comments directly to the parliamentary agency that advises members of parliament.

Finally, a student-created citizen governance wiki called LexPop was recently created as the first legislative wiki platform in the USA (the website has since been put on hiatus until January 2013). Despite the uncharted territory, a Massachusetts state legislator agreed to propose a bill on net neutrality on LexPop for the site's users to draft [66].

\section{Challenges and responses to the wiki-governance model}

A biobank wiki-governance model is not flawless. The following points delineate what we believe are the main concerns that can be raised. (1) A closed system of experts (be they scientists, lawyers or ethicists) is better suited to craft complex governance policies; the madness of crowds is a genuine concern [48]. (2) Unless there is rational (for example, language compatibility, effective visualizations with specific, focused questions and topics), impartial (for example, agendas are framed in a non-loaded manner by those not seeking any one desired outcome) and appealing (for example, user friendly) design of a wiki-governance forum to present a generally understandable view of citizen collaboration, it is possible that confusion, narrow interest group commandeering or tune-out may ensue [49]. (3) Unlike Wikipedia and open source, wiki-governance involves collaborative efforts on both factual and normative issues. This is a new paradigm and there are as yet few examples of normatively driven policies truly crafted by publics. (4) Wiki-governance is difficult to scale and it is time and money sensitive. Capital investments must be made to properly run and maintain the IT logistics of the forums. (5) Policies must at some point be released; therefore, it falls upon someone to determine when the time is right to deem a policy final. (6) Though rapidly shrinking, the digital divide remains, so not all citizens, be they state or global, can have a legitimate voice in the collaborative decision and policymaking process. (7) Small, pinpoint-focused contributions by citizens may lead to problems in seeing the big picture of a biobank policy. (8) Drafting policies requires a certain degree of technical skill (though this can be remedied with policy consultants, tutorials and a wikisandbox to practice, as well as FAQs). (9) An underresearched subject that is especially pertinent here is the paradox of public engagement and biobank governance in the 21st century: policy harmonization is increasingly seen as a necessity for translational research [50,51], yet greater public engagement could produce more policy variability based on local cultures, politics, values and histories.

These are neither insurmountable nor fatal hurdles. As a rejoinder to the 'madness of crowds' argument, we reject the 'public knowledge deficit' thesis; the putative ignorance of publics is not an obstacle (if it exists at all), but rather an opportunity to foster symmetry of knowledge and learning processes between purported experts and non-experts [52]. We also emphatically oppose institutional fetishism that places trust in only recognized experts for science and policy [53]. We believe that, (arguably) unlike in a wiki model for research, a wiki model for governance and policymaking necessitates real expertise, which for us is broadly defined to include all individuals with scientific knowledge and popular experience that can effectively supplement the knowledge of inside, traditional and creditionalized governance experts [54]. The self-policing nature of a wiki, united with 
diversification of decision-making processes into many constituent parts through various technologies, limits the risk of tyrannical factions and interest group commandeering. If a wiki-governance forum is designed (itself, in a collaborative and transparent manner) to facilitate teamwork and group projects rather than solo one-off contributions and is coupled with reputational metrics for participating citizens (that is, a rating system of the best contributors), potentials for tune-out, frivolous participation or collective distrust of working anonymously across distances could dissipate and at the same time augment participation rates.

As a rejoinder to the paradox of policy harmonization, it may well be that different biobanks require different means of engaging in their social environment to include publics; the price of welcoming a diversity of different biobank constituencies is heterogeneous structures [23,55]. Harmonization of basic epidemiological and policy tools - distinct from harmonization of ethics [56] - is possible and in fact advisable, given increasingly collaborative transnational research and transfer of data and samples [57]. This is an ongoing aim of the Public Population Project in Genomics and Society $\left(P^{3} G\right)[58]$, an international consortium dedicated to the harmonization of policies and research tools for large biobank projects across the world.

Global approaches to some aspects of governance are currently being assessed. DataSHIELD [59] is a bioinformatics tool to provide access to research results via simultaneous parallelized analysis of the individual-level, harmonized data from each study, without breaching data protection or privacy laws and research governance requirements. The Ensuring Consent and Revocation (EnCoRe) project [60] empowers individuals to control their consent and shape what happens to the personal information they disclose to organizations. The Open Research and Contributor ID (ORCID) [61] initiative creates a central registry of unique identifiers for researchers and a linking mechanism between the registry and other current author identity schemes so as to facilitate scientific discovery and global research community collaboration. And the BioResource Impact Factor (BRIF) [62] project seeks to provide a global registry for databases and allow a unique identifier to cite and acknowledge the use of bioresources in publications, thereby measuring their impact. The project aims to assist groups in tracking submissions and data release and promote the international sharing of bioresources [63].

Harmonization is conceptually and operationally distinct from a one-size-fits-all regulatory approach. Broad-based, shared scientific, legal, and ethical norms can be a foundation upon which kaleidoscopic, but global and digitally linked governance architectures, can be built. This is the aim of the newly established, $P^{3} G$-hosted
ELSI 2.0 Initiative, for instance, which mobilizes networked international collaboration in ethical, legal and social implications (ELSI) research by establishing a web-based research collaboratory infrastructure for publics that will accelerate the translation of ELSI research findings into practice and policy [64].

We acknowledge, nonetheless, that these obstacles hinder a fully libertarian wiki. A workable wiki-governance model may therefore be a modular, collaborative one, where citizens participate in and vote on a given proposal, protocol, policy or more contentious aspect of the project, and submit it to the biobank management committee, who must, acting as a central arbiter, then post a response, explaining what action was taken and why. Each time components of a biobank's governance beckon revision (whether through voting on the wiki forum, imposed periodic review of a policy or management committee decision), the wiki-governance process outlined in Figure 1 would repeat itself and the biobank management committee would be called upon to act.

\section{Concluding remarks}

Even in the blazingly fast world of genomics and biomedical research, large-scale, population-based biobanks are still a rather new phenomenon. Much progress has been made in a short period of time to better respect and incorporate the views of those upon whom the success of a biobank stands: citizens. Now that much of the world is entering an era of perpetual online existence and social media technology where youth are particularly active participants, new tools can and should be utilized to gauge public sentiment, engage citizen collaboration, share work and embrace the wisdom of crowds [48]. If 'the relational, open and global nature of modern science is leading to more devolved regulatory approaches' [65], and if the success of a biobank depends on an effective 'strategy for patterning a network of interaction' [23], paladins of participatory democracy should view wikigovernance as a promising avenue. Indeed, we think it can spawn new biosocial group identities $[66,67]$ and lead to the establishment of biobanks from the bottom up, by citizens rightfully envisioning themselves as co-creators of genomic science and policy. At a minimum, wikigovernance would be a welcome application of biobankers' fundamental socio-ethical aspirations of public understanding, engagement and motivation, trust, transparency and open dialogue, thus simultaneously promoting scientific aspirations of successful translational research. In the spirit of such engagement and open dialogue, we encourage the entire readership to submit their comments on our model.

Abbreviation

ELSI, ethical, legal and social implications. 


\section{Competing interests}

The authors declare that they have no competing interests.

\section{Acknowledgements}

All of the authors are grateful for the funding support of Genome Canada, Genome Quebec, and the Public Population Project in Genomics and Society $\left(P^{3} G\right)$

Published: 29 May 2012

\section{References}

1. Hunter KG, Laurie G: Involving publics in biobank governance: Moving beyond existing approaches. In The Governance of Genetic Information: Who Decides? Edited by Widdows H. Cambridge: Cambridge University Press; 2009:151-177.

2. Burgess $M, O$ 'Doherty $K$, Secko D: Biobanking in British Columbia: discussions of the future of personalized medicine through deliberative public engagement. Per Med 2009, 5:285-296.

3. Avard D, Bucci LM, Burgess MM, Kaye J, Heeney C, Cambon-Thomsen A: Public health genomics (PHG) and public participation: points to consider. J Public Deliberation 2009, 5:2-21.

4. Dove ES: The genetic privacy carousel: a discourse on proposed genetic privacy bills and the co-evolution of law and science. Curr Pharmacogenomics Person Med 2011, 9:252-263.

5. Marris $C$, Rose N: Open engagement: exploring public participation in the biosciences. PLOS Biol 2010, 8:e1000549.

6. Xenos MA, Becker AB, Anderson AA, Brossard D, Scheufele DA: Stimulating upstream engagement: an experimental study of nanotechnology information seeking. Soc Sci O 2011, 92:1191-1214.

7. Lemke AA, Halverson C, Ross LF: Biobank participation and returning research results: perspectives from a deliberative engagement in South Side Chicago. Am J Med Genet A 2012, 158A:1029-1037.

8. O'Doherty KC, Burgess MM, Edwards K, Gallagher RP, Hawkins AK, Kaye J, McCaffrey V, Winickoff DE: From consent to institutions: designing adaptive governance for genomic biobanks. Soc Sci Med 2011, 73:367-374.

9. Kaye J, Gibbons SMC, Heeney C, Parker M, Smart A: Governing Biobanks: Understanding the Interplay between Law and Practice. Oxford: Hart Publishing; 2012.

10. Gottweis $\mathrm{H}$, Chen $\mathrm{H}$, Starkbaum J: Biobanks and the phantom public. Hum Genet 2011, 130:433-440.

11. Laurie G: Reflexive governance in biobanking: on the value of policy led approaches and the need to recognise the limits of law. Hum Genet 2011, 130:347-356

12. Hagendijk R, Irwin A: Public deliberation and governance: engaging with science and technology in contemporary Europe. Minerva 2006, 44:167-184.

13. Greely HT: Ethical issues in the Human Genome Diversity Project. In The Encyclopedia of Ethical, Legal and Policy Issues in Biotechnology. Volume 1 Edited by Murray TH, Mehlman MJ. New York: John Wiley and Sons; 2000:552-566

14. Rose H: An ethical dilemma. The rise and fall of UmanGenomics - the model biotech company? Nature, 2003 425:123-124.

15. Cardinal G, Deschênes M: Surveying the population biobankers. In Populations and Genetics: Legal and Socio-Ethical Perspectives. Edited by Knoppers BM. Leiden and Boston: Martinus Nijhoff; 2003:37-94.

16. Pálsson G: The rise and fall of a biobank: the case of Iceland. In Biobanks: Governance in Comparative Perspective. Edited by Gottweis H, Petersen A. London and New York: Routledge; 2008:41-55.

17. McHale JV: Accountability, governance and biobanks: the ethics and governance committee as guardian or as toothless tiger? Health Care Anal 2011, 19:231-246.

18. Winickoff $D E$ : From benefit sharing to power sharing: partnership governance in population genomics research. In Principles and Practice in Biobank Governance. Edited by Kaye J, Stranger M. Farnham: Ashgate: 2009:53-66

19. Winickoff $D E$ : Partnership in UK Biobank: a third way for genomic property? J Law Med Ethics 2007, 35:440-456.

20. Knoppers $B M$, Chadwick R: Human genetic research: emerging trends in ethics. Nat Rev Genet 2005, 6:75-79.

21. Gottweis H, Gaskell G, Starkbaum J: Connecting the public with biobank research: reciprocity matters. Nat Rev Genet 2011, 12:738-739.
22. Onyx J, Kenny S, Brown K: Active citizenship: an empirical investigation. Social Policy Soc 2011, 11:55-66.

23. Gottweis H, Lauss G: Biobank governance: heterogeneous modes of ordering and democratization. J Community Genet 2012, 3:61-72.

24. Noveck BS: Wiki Government: How Technology Can Make Government Better, Democracy Stronger, and Citizens More Powerful. Washington, DC: Brookings Institution Press; 2009.

25. Gibbons SMC: Regulating biobanks: a twelve-point typological tool. Med Law Rev 2009, 17:313-346.

26. Gibbons SMC, Kaye J, Smart A, Heeney C, Parker M: Governing genetic databases: challenges facing research regulation and practice. J Law Soc 2007, 34:163-189.

27. Zittrain J: The lessons of Wikipedia. In The Future of the Internet and How to Stop It. New Haven, CT: Yale University Press; 2008:127-148.

28. Salzberg SL: Genome re-annotation: a wiki solution? Genome Biol 2007 8:102.

29. Mons B, Ashburner M, Chichester C, van Mulligen E, Weeber M, den Dunnen J, van Ommen GJ, Musen M, Cockerill M, Hermjakob H, Mons A, Packer A, Pacheco R, Lewis S, Berkeley A, Melton W, Barris N, Wales J, Meijssen G, Moeller E, Roes PJ, Borner K, Bairoch A: Calling on a million minds for community annotation in WikiProteins. Genome Biol 2008, 9:R89.

30. Hoehndorf R, Bacher J, Backhaus M, Gregorio SE Jr, Loebe F, Prüfer K, Uciteli A, Visagie J, Herre H, Kelso J: BOWiki: an ontology-based wiki for annotation of data and integration of knowledge in biology. BMC Bioinformatics 2009, 10(Suppl 5):S5

31. Stehr H, Duarte JM, Lappe M, Bhak J, Bolser DM: PDBWiki: added value through community annotation of the Protein Data Bank. Database (Oxford) 2010, 2010:baq009

32. Stokes TH, Torrance JT, Li H, Wang MD: ArrayWiki: an enabling technology for sharing public microarray data repositories and meta-analyses. BMC Bioinformatics 2008, 9(Suppl 6):S18.

33. Das S, Girard L, Green T, Weitzman L, Lewis-Bowen A, Clark T: Building biomedical web communities using a semantically aware content management system. Brief Bioinform 2009, 10:129-138.

34. Irwin A: Citizen Science: A Study of People, Expertise and Sustainable Development. New York: Routledge; 1995

35. Weldon S: 'Public consent' or 'scientific citizenship'? What counts as public participation in population based biobanks? In Genetic Databases: SocioEthical Issues in the Collection and Use of DNA. Edited by Tutton R, Corrigan O. London: Routledge; 2004:161-181.

36. Corbyn Z: Could crowd sourcing provide the next genetics breakthrough? [http://blogs.nature.com/news/2011/12/could_crowd_sourcing_provide_t. html]

37. Kaye J, Curren L, Anderson N, Edwards K, Fullerton SM, Kanellopoulou N, Lund D, Macarthur DG, Mascalzoni D, Shepherd J, Taylor PL, Terry SF, Winter SF: From patients to partners: participant-centric initiatives in biomedical research. Nat Rev Genet 2012, 13:371-376.

38. Arita M: A pitfall of wiki solution for biological databases. Brief Bioinform 2009, 10:295-296.

39. Saha K, Hurlbut JB: Treat donors as partners in biobank research. Nature 2011, 478:312-313

40. Kosslyn SM: On the evolution of human motivation: the role of social prosthetic systems. In Evolutionary Cognitive Neuroscience. Edited by Platek SM, Shackelford TK, Keenan JP. Cambridge, MA: MIT Press; 2006:541-554.

41. Stranger M, Kaye J: Governing biobanks: an introduction. In Principles and Practice in Biobank Governance. Edited by Kaye J, Stranger M. Franham: Ashgate; 2009:1-12.

42. Hapgood R, McCabe C, Shickle D: Public preferences for participation in a large DNA cohort study: a discrete choice experiment. Discussion paper series 04/5. Sheffield: University of Sheffield ScHARR (School of Health and Related Research), Sheffield Health Economics Group; 2004

43. Levitt M: Relating to participants: how close do biobanks and donors really want to be? Health Care Anal 2011, 19:220-230.

44. Pateman C: Participatory democracy revisited. Perspectives Politics 2012 10:7-19.

45. van der Merwe R, Meehan A: Direct deliberative governance online: consensual problem solving or accommodated pluralism? I Information Technol Politics 2012, 9:46-63.

46. Stromer-Galley J, Webb N, Muhlberger P: Deliberative e-rulemaking project: challenges to enacting real world deliberation. I Information Technol Politic 2012, 9:82-96. 
47. Özdemir V, Faraj SA, Knoppers BM: Steering vaccinomics innovations with anticipatory governance and participatory foresight. OMICS 2011 15:637-646.

48. Petsko GA: The wisdom, and madness, of crowds. Genome Biol 2008, 9:112

49. Papaioannou T: Democratic governance of genomics: the case of UK Biobank. New Genet Soc 2012, 31:111-133.

50. Kaye J: From single biobanks to international networks: developing egovernance. Hum Genet 2011, 130:377-382.

51. Chalmers D: Genetic research and biobanks. Methods Mol Biol 2011 , 675:1-37.

52. Lehoux P: Moving beyond our mutual ignorance. Or, how would engaging the public benefit the personalized medicine community? Curr Pharmacogenomics Person Med 2011, 9:76-79.

53. Unger R: What Should Legal Analysis Become? London: Verso; 1999

54. Hoeyer K: Donors perceptions of consent to and feedback from biobank research: time to acknowledge diversity. Public Health Genomics 2010, 13:345-352.

55. Knoppers BM, Harris JR, Tassé AM, Budin-Ljøsne I, Kaye J, Deschênes M, Zawati MH: Towards a data sharing Code of Conduct for international genomic research. Genome Med 2011, 3:46.

56. Rial-Sebbag E, Cambon-Thomsen A: The emergence of biobanks in the legal landscape: towards a new model of governance. J Law Soc 2012, 39:113-130.

57. Joly Y, Dove ES, Kennedy KL, Bobrow M, Ouellette BFF, Dyke SOM, Kato K, Knoppers BM: Open science and community norms: data retention and publication moratoria policies in genomics projects. Med Law Int, in press.

58. $\mathrm{P}^{3} \mathrm{G}$ [http://p3g.org]

59. $P^{3} G$ Observatory [http://www.p3gobservatory.org/datashield/ summary.htm]

60. EnCoRe [http://www.encore-project.info/]

61. ORCID [http://about.orcid.org/]

62. G2P Knowledge Centre [http://www.gen2phen.org/groups/ brif-bio-resource-impact-factor]

63. Cambon-Thomsen A, Thorisson GA, Mabile L: The role of a Bioresource Research Impact Factor as an incentive to share human bioresources. Nat Genet 2011, 43:503-504
64. Kaye J, Meslin EM, Knoppers BM, Juengst ET, Deschênes M, CambonThomsen A, Chalmers D, De Vries J, Edwards K, Hoppe N, Kent A, Adebamowo C, Marshall P, Kato K: ELSI 2.0 for genomics and society. Science 2012, 336:673-674

65. Knoppers BM: Genomics and policymaking: from static models to complex systems? Hum Genet 2009, 125:375-379.

66. Zwart $\mathrm{H}$ : Genomics and identity: the bioinformatisation of human life. Med Health Care Philos 2009, 12:125-136.

67. Sándor J, Bárd P, Tamburrini C, Tännsjö T: The case of biobank with the law: between a legal and scientific fiction. J Med Ethics 2012, 38:347-350.

68. Watson PH, Barnes RO: A proposed schema for classifying human research biobanks. Biopreserv Biobank 2011, 9:327-333.

69. Council of Europe: Recommendation Rec(2006)4 of the Committee of Ministers to Member States on Research on Biological Materials of Human Origin Strasbourg: Council of Europe; 2006.

70. Dove ES, Black L, Avard D, Knoppers BM: Privacy in Canadian paediatric biobanks: a changing landscape. A report delivered to the Office of the Privacy Commissioner of Canada. [http://www.humgen.org/int/Gl/ Privacy_in_Canadian_paediatric_Biobanks.pdf]

71. Do Tank [http://dotank.nyls.edu/]

72. WikiVote [http://www.wikivote.ru/]

73. Economist Staff: Citizen lawmaking: Government by (all) the people. Economist 2011,73 [http://www.economist.com/node/21534760]

74. Crowdexpert [http://edu.crowdexpert.ru/node/64]

75. Osalusveeb [https://www.osale.ee/]

76. New York Times Staff: The 7th annual year in ideas. NY Times (Print) 2007, 80 [http://www.nytimes.com]

77. e-Democracia [http://edemocracia.camara.gov.br/]

doi:10.1186/gb-2012-13-5-158

Cite this article as: Dove ES, et al:: Power to the people: a wiki-governance model for biobanks. Genome Biology 2012, 13:158. 